\title{
Study of G6pd Deficit (Glucose-6-phosphate Deshydrogenase) in Blood Donors in Brazzaville
}

\author{
M'pene Bel Varret ${ }^{1, \text { * }}$, Fouti Gudrid Ludmilhia ${ }^{2}$, Arsène Bikoue $^{3}$, Ongouda Brunel ${ }^{4}$, \\ Nguimbi Etienne ${ }^{4}$ \\ ${ }^{1}$ Unit of Biochemistry and Molecular Biology, Faculty of Health Sciences, University Marien Ngouabi, Brazzaville, Congo \\ ${ }^{2}$ Hematology Laboratory, Faculty of Health Sciences, University Marien Ngouabi, Brazzaville, Congo \\ ${ }^{3}$ Immunohematology Laboratory, National Blood Transfusion Center, Brazzaville, Congo \\ ${ }^{4}$ Cellular and Molecular Biology Laboratory, Faculty of Technical Sciences, University Marien Ngouabi, Brazzaville, Congo
}

\section{Email address:}

Varretmpene@yahoo.fr (M. B. Varret), Belvarret@gmail.com (M. B. Varret)

${ }^{*}$ Corresponding author

\section{To cite this article:}

M'pene Bel Varret, Fouti Gudrid Ludmilhia, Arsène Bikoue, Ongouda Brunel, Nguimbi Etienne. Study of G6pd Deficit (Glucose-6phosphate Deshydrogenase) in Blood Donors in Brazzaville. Biomedical Sciences. Vol. 6, No. 4, 2020, pp. 84-88.

doi: $10.11648 /$ j.bs.20200604.12

Received: September 29, 2020; Accepted: October 17, 2020; Published: October 23, 2020

\begin{abstract}
Glucose-6-Phosphate dehydrogenase (G6PD) is an enzyme present in the cytoplasm of all cells in the body and protects red blood cells from certain attacks. The anomaly is genetically inherited in a recessive manner, linked to the $\mathrm{X}$ chromosome. Currently, an estimated 420 million individuals lack G6PD worldwide and its incidence varies between 1-25\% in some African populations. This was an analytical cross-sectional study with prospective data collection that took place from May to November 2018, i.e. six (6) months. Our study included 108 blood donors, 88 men and 20 women. The samples were stored at $2-8{ }^{\circ} \mathrm{C}$ for 24 hours while awaiting handling. The determination of the enzymatic activity of G6PD was carried out by the spectrophotometric method using a commercially available kit. 02/108 subjects studied (ie a prevalence of $1.85 \%$ ) were deficient in our study. These two deficit were mostly young and between 18-25 years old only male. They were originally from the plateau and observed in the blood transfusion station (PTS) of the Talangai referral hospital. The mean hemoglobin value in normal subjects was $12.53 \mathrm{~g} / \mathrm{dl}$ in men and $11.3 \mathrm{~g} / \mathrm{dl}$ in women. In contrast, the average hemoglobin value was $10.45 \mathrm{~g} / \mathrm{dl}$ in the deficient patients. The mean value of G6PD enzyme activity in normal subjects was $11.7 \mathrm{IU} / \mathrm{g}$ hemoglobin in men, $11.54 \mathrm{IU} / \mathrm{g}$ hemoglobin in women and in deficient subjects was $2.83 \mathrm{IU} / \mathrm{g}$ hemoglobin. As the results of our study show, G6PD deficiency affects hemoglobin levels.
\end{abstract}

Keywords: Prevalence, G6PD Deficit, Blood Donors, Congo Brazzaville

\section{Introduction}

Glucose-6-phosphate-dehydrogenase (G6PD) is the first enzyme in anaerobic glycolysis or the pentose phosphate pathway. It is the first enzyme described by Warburg and Christian in 1931, it consists of 515 amino acids with a molecular weight of $59 \mathrm{KDa}$ [1-3] and in active form, it consists of identical subunits of dimers and tetramers, the proportion of these two forms is $\mathrm{pH}$ dependent [4].

G6PD is an enzyme found in the cytoplasm of all cells in the body. It is used to protect red blood cells from certain attacks. With G6PD deficiency, the enzyme no longer performs its role optimally, which does not automatically mean that the enzyme does not work. It also plays an essential role in the elimination of peroxides in the red blood cell; in fact NADPH (reduced Nicotinamide adenine dinucleotide phosphate) resulting from anaerobic glycolysis allows the reduction of glutathione, the latter is essential for the reduction of toxic peroxides.

G6PD deficiency is a hereditary deficit of red blood cells which may be responsible for hemolysis and therefore the cause of hemolytic anemia. People with this deficiency are generally normal and healthy, except in one of the forms of the deficiency which results in mild but chronic anemia.

Infections, ingestion of beans or taking certain drugs such as certain antimalarials, anti-inflammatories, antibiotics 
would expose the deficient subject to a hemolytic crisis.

Several variants (about 160 different mutations) have been identi fi ed, with a characteristic geographic distribution. Among the three main existing variants ("A-" variant, Mediterranean variant and canton variant), the "A- " variant is found in black subjects [5].

The abnormality is genetically inherited recessively, linked to the $\mathrm{X}$ chromosome and is therefore not contagious. G6PD deficiency cannot be caught, deficits are born with it. The transmission of G6PD deficiency is linked to gender. The gene encoding G6PD is located on the terminal region of the long arm of the $\mathrm{X}$ chromosome at position q28 near the gene encoding factor VIII. The gene has a size of $18 \mathrm{~Kb}$ consisting of 13 exons transcribed into $2.269 \mathrm{~Kb}$ mRNA with $1.545 \mathrm{~Kb}$ of coding regions.

G6PD deficiency was discovered in the 1950s following studies on the hemolyzing power of primaquine, a synthetic antimalarial [5].

This enzyme is sometimes found to be deficient in certain individuals. Currently, an estimated 420 million people are deficient in G6PD worldwide. As such, G6PD deficiency is the most frequent erythrocytic enzymopathy [6-9]. G6PD is particularly common in Mediterranean countries, Africa and tropical Asia, but can be encountered in all geographic areas due to population movements [10]. Its incidence varies between $1-25 \%$ in some African populations.

In Congo Brazzaville, a study carried out in 1998 on G6PD deficiency and homozygous sickle cell disease reported a prevalence of $22.5 \%$ [11]. Data on the prevalence of G6PD deficiency among blood donors in the Republic of Congo are not available.

Given the high frequency of transfusions, most of the patients receiving blood products are on medication; transfusion of a unit of blood from a G6PD-deficient blood donor may be ineffective. This is especially so as there are sometimes cases of poor performance after certain red blood cell transfusions in some recipients of these products, who often take drugs that are sometimes oxidizing agents of G6PDdeficient red blood cells. It is therefore not excluded to have certain healthy carriers of this deficiency in the Congolese population in general and in blood donors in particular. Thus we propose by this study to verify its existence within the population of blood donors in Brazzaville.

\section{Material and Methods}

Description of the study location and data collection: The study was carried out at the National Blood Transfusion Center (CNTS) more precisely at the Blood Transfusion Station (PTS) of the Talangaï referral hospital and at the PTS of the Hospital Center and University (CHU) of Brazzaville, structures for collecting samples and referral of blood products. The technical operations were carried out at the Brazzaville CHU laboratory in the hematology and biochemistry department. The CHU is located in the IV district (Moungali) and the laboratory building is located opposite the intensive care unit.
Study population: The study population was composed of Volunteer blood donors (blood donor making a first blood donation), Regular (loyal blood donor) and family (compensation donor).

Storage: The samples were stored at a temperature of $2-8^{\circ}$ $\mathrm{C}$ for 24 hours while awaiting handling.

Statistical analysis: Data were entered on Microsoft Office Excel 2013. Data processing and analysis were performed on GraphPad Prism 7 software. The Student Fischer two-tailed test was used for comparison of proportions and cutoff. significance was set at $\mathrm{p}<0.05$.

\section{Results and Discussion}

Results

"1." Descriptive Results

The overall population consisted of 108 donors with a sex ratio $=4.4$ in favor of the male sex, or $81.5 \%$ and an average age of $31.95 \pm 9.48$ years. It was 108 blood donors who had left for two different centers and there was a predominance of men in both centers. The blood donors in our study were selected in Brazzaville. The survey form questionnaire made it possible to determine their ethnicity. The most dominant ethnicity was that of the plateau followed by the pool and the basin. The two deficits in our study were plateau and male.

"1.1" Socio-demographic Data

Table 1. Distribution of the study population according to age groups.

\begin{tabular}{lll}
\hline Age (years) & Effective & \% \\
\hline $18-25$ & 30 & 27,8 \\
$26-35$ & 43 & 39,8 \\
$36-45$ & 22 & 20,4 \\
$46-55$ & 13 & 12,0 \\
Total & 108 & 100 \\
\hline
\end{tabular}

$\%$, Percentages.

The mean age of the subjects studied was $31.95 \pm 9.48$ years and corresponded to the modal class of 26-35 years.

Table 2. Distribution of the study population by sex.

\begin{tabular}{lll}
\hline Sex & Effective & \% \\
\hline Men & 88 & $81,5 \%$ \\
Women & 20 & $18,5 \%$ \\
Total & 108 & $100 \%$ \\
\hline
\end{tabular}

The global population consisted of 108 donors with a sex ratio $=4.4$ in favor of the male sex, or $81.5 \%$.

Table 3. Distribution of the study population by ethnicity.

\begin{tabular}{lll}
\hline Ethnic group & Effective & \% \\
\hline Cuvette & 19 & $17,59 \%$ \\
Likouala & 1 & $0,93 \%$ \\
Plateau & 46 & $42,59 \%$ \\
Pool & 42 & $38,89 \%$ \\
Total & 108 & $100 \%$ \\
\hline
\end{tabular}

The most dominant ethnicity was that of the plateaux with a frequency of $42.59 \%$ followed by the Pool and the Cuvette. 
Table 4. Distribution of the study population by center according to sex.

\begin{tabular}{|c|c|c|c|c|c|c|}
\hline & \multicolumn{2}{|c|}{ PTS-CHU } & \multicolumn{2}{|c|}{ PTS-TALANGAÏ } & \multicolumn{2}{|l|}{ Total } \\
\hline & Effective & $\%$ & Effective & $\%$ & Effective & $\%$ \\
\hline Men & 41 & 38,0 & 47 & 43,5 & 88 & 81,5 \\
\hline Women & 14 & 13,0 & 6 & 5,5 & 20 & 18,5 \\
\hline TOTAL & 55 & 51,0 & 53 & 49,0 & 108 & 100 \\
\hline
\end{tabular}

The 108 donors constituting the overall population were distributed among the 2 main collection centers, ie 55 donors at PTS-CHU and 53 at PTS-Talangaï. There was a predominance of men in both centers.

"1.2" Biological Data

Table 5. Distribution of the study population according to the type of G6PD activity.

\begin{tabular}{llllll}
\hline \multirow{2}{*}{ Activity G6PD } & Man & & Women & \multicolumn{2}{c}{ TOTAL } \\
\cline { 2 - 6 } & $\mathbf{n}$ & $\mathbf{\%}$ & $\mathbf{N}$ & $\mathbf{\%}$ & $\mathbf{N}$ \\
\hline Normal & 86 & 79,63 & 20 & 18,52 & 106 \\
Deficit & 2 & 1,85 & $/$ & $/$ & 2 \\
Total & 88 & & 20 & 1,85 & 108 \\
\hline
\end{tabular}

The prevalence of G6PD deficiency in our study is $1.85 \%$.

Table 6. Distribution of the population by origin and activity of G6PD.

\begin{tabular}{lllll}
\hline \multirow{2}{*}{ Ethnic group } & Activity G6PD & Normal & & Deficits \\
\cline { 4 - 5 } & Effective & \% & Effective \\
\hline Cuvette & 19 & 17,59 & $/$ \\
Likouala & 1 & 0,93 & $/$ & \% \\
Plateau & 44 & 40,74 & 2 & $/$ \\
Pool & 42 & 38,89 & $/$ & 1,85 \\
Total & 106 & 98,15 & $/$ & 2 \\
\hline
\end{tabular}

Among the 108 identified donors, we noted deficits mainly from the plateaus, either $1.85 \%$ of the overall population.

"1.3" Analytical Data

Table 7. Relationship between G6PD and sex.

\begin{tabular}{|c|c|c|c|c|c|c|}
\hline G6PD & Normal & & & & Tota & \\
\hline Sex & $\mathbf{N}$ & $\%$ & $\mathbf{N}$ & $\%$ & $\mathbf{N}$ & $\%$ \\
\hline Men & 86 & 79,63 & 2 & 1,85 & 88 & 81,48 \\
\hline Women & 20 & 18,52 & 1 & I & 20 & 18,52 \\
\hline Total & 106 & 98,15 & 2 & 1,85 & 108 & 100 \\
\hline
\end{tabular}

$\mathrm{N}=$ effective

All of the deficits were male.

Table 8. Relationship between G6PD and the different age classes.

\begin{tabular}{lllllll}
\hline \multirow{2}{*}{ Age (years) } & G6PD & Normal & \multicolumn{5}{l}{ Deficits } & Total & $\mathbf{N}$ & \% \\
\cline { 2 - 7 } & $\mathbf{N}$ & $\mathbf{\%}$ & $\mathbf{N}$ & $\mathbf{\%}$ & 30 & 27,78 \\
\\
\cline { 2 - 8 }-25 & 28 & 25,93 & 02 & 1,85 & 43 & 39,81 \\
$26-35$ & 43 & 39,81 & $/$ & $/$ & 22 & 20,37 \\
$36-45$ & 22 & 20.37 & $/$ & $/$ & 13 & 12,04 \\
$46-55$ & 13 & 12,04 & $/$ & $/$ & 108 & 100 \\
Total & 106 & 98,15 & 02 & 1,85 & \\
\hline
\end{tabular}

$\mathrm{N}=$ actual $\%=$ percentage

The two deficits were observed in the age group 18 to 25 years.

Table 9. Average values of hemoglobin and G6PD activity in normal subjects.

\begin{tabular}{lllll}
\hline \multirow{2}{*}{ SEX } & \multirow{2}{*}{$\mathbf{n}$} & HEMOGLOBIN (g/dI) & G6PD (UI/gHb) & p \\
\cline { 3 - 5 } & & Average \pm ET & Average \pm ET & $0,0021^{*}$ \\
Men & 86 & $12,53 \pm 1,19$ & $11,7 \pm 0,11$ & $0,6227^{\text {NS }}$ \\
Women & 20 & $11,3 \pm 1,94$ & $11,54 \pm 0,95$ & \\
P & & $0,0060^{*}$ & $0,5373^{\text {NS }}$ & $0,0021^{*}$ \\
Total & 106 & $12,30 \pm 0,18$ & $11,67 \pm 0,11$ & \\
\hline
\end{tabular}

NS=Not Significant $*=$ Significant AND $=$ Standard deviation.

The correlation between hemoglobin and the enzymatic activity of G6PD in non-deficient individuals is statistically significant with a significance level $\mathrm{p}=0.0021$. Singularly, the difference between these two parameters did not show any 
significant differences in women unlike men.

Table 10. Mean values of hemoglobin and G6PD activity in deficient subjects.

\begin{tabular}{|c|c|c|c|c|}
\hline \multirow{2}{*}{ SEX } & \multirow{2}{*}{$\mathbf{n}$} & HEMOGLOBIN (g/dl) & G6PD (UI/gHb) & \multirow[b]{2}{*}{$\mathbf{p}$} \\
\hline & & Average $\pm E T$ & Average $\pm \mathrm{ET}$ & \\
\hline Man & 2 & $10,45 \pm 0,15$ & $2,83 \pm 0,65$ & $0.0076^{*}$ \\
\hline Women & 0 & l & I & \\
\hline Total & 2 & $10,45 \pm 0,15$ & $2,83 \pm 0,65$ & $0.0076^{*}$ \\
\hline
\end{tabular}

*=Significant $\mathrm{AND}=$ Standard deviation

Only seen in the men in our study, the correlation between hemoglobin and G6PD enzymatic activity of deficient people is statistically significant with a $p$ value $=0.0076$.

\section{Discussion}

Our study was cross-sectional and took place during the period from May to November 2018, i.e. six (6) months. We used a method that has already been described, spectrophotometric method or reference method from the CYPRESS DIAGNOSTIC laboratory for the determination of the enzymatic activity of G6PD. This is a technique that has the advantage of being practicable in almost all laboratories; to be reproducible even with blood stored at $2-8^{\circ}$ for 24 hours. In the study by HUSSEIN et al, 2011 in Yemen, the storage of their samples was between $2-6^{\circ} \mathrm{C}$ and processed 48 hours after collection using the spectrophotometric technique [12]. The reagents for this test are delivered in a carton containing six (6) vials (reagent R1, R2, R3, R4, normal and low control) for sixty (60) samples. This test makes it possible to distinguish the deficient from the non-deficient but does not make it possible to confirm the degree of the deficiency or the variant involved. It is recommended to do the molecular biology test to determine the enzyme variant.

In addition, several techniques have also been described, almost all of them provide satisfactory results: Reduced Glutathione (GSH) Stability Test, NADP Reduction Test, Fluorescent Spot Test or Beutler Spot Test, Body Research Heinz, the molecular biology test...

Thus in our study we found two deficient in G6PD. These two deficits were male and were from the plateau.

The donors in our study were between $18-55$ years old and the most dominant age group was 26-35 years, or $39.8 \%$. This observation is similar to the results of the study by AMADOU et al in 2005 in Mali on G6PD deficiency in blood donors from CNTS BAMAKO, also reported a dominant class of 26-35 years [13]. On the other hand, the study carried out in the Democratic Republic of Congo by MUKUKU et al in 2016 had reported a dominant class of 2029 years [14], and in Mali, GUITTEYE in 2003 the age group was respectively 18 to 29 years [15].

The distribution by sex in our study showed that the male sex was in the majority with $81.5 \%$ and $18.5 \%$ for the female sex. This male predominance was also observed in the studies reported by AMADOU et al in 2005 in Mali on the
G6PD deficiency in blood donors from the CNTS of BAMAKO, the majority population was male, ie $85.3 \%$ [13]. In another study also in Mali in 2002 by OUMOU et al on the erythrocyte phenotype in immunogenic blood group systems in BAMAKO blood donors had reported a predominance of men, ie $86.5 \%$ [16]. Indeed, this can be explained by the many contraindications to donating blood in women, namely breastfeeding, pregnancy, menstruation, which would limit women to donating blood.

The most dominant ethnicity in our study was that of the plateaux with a frequency of $42.59 \%$ followed by the Pool and the Cuvette. Previous studies carried out in Mali despite the difference in geography, ethnic origin, OUMOU et al in 2002 on the erythrocyte phenotype in immunogenic blood group systems in BAMAKO blood donors had found Bambara as the dominant ethnicity with a frequency of $30.9 \%$ [16].

By looking at the distribution of blood donors by center, we found that the PTS at CHU has many more blood donors than the PTS at Talangai. Indeed, the transfusion activity is important at the PTS of CHU and this center is frequented a lot by blood donors.

Analysis of glucose-6-phosphate dehydrogenase (G6PD) enzyme activity in our study gave us a prevalence of $1.85 \%$.

This study result differs with the results found by AKANNI et al in 2010 in Nigeria on glucose-6-phosphate dehydrogenase (G6PD) deficiency in blood donors and newborns with jaundice in Osogbo Nigeria reported the prevalence of G6PD deficit in blood donors of $19.5 \%$ in Osogbo Osun State [17]. On the other hand, AMADOU et al in 2005 in Mali on the G6PD deficiency in blood donors from the CNTS of BAMAKO, had found a prevalence of $16.2 \%$ and all the deficits were male [13].

The fairly large difference in the prevalence rate on G6PD deficiency in our different studies may be due to the variability in the sample size and the method used.

Among the 108 identified donors, we noted deficits mainly from the plateau region and male. Indeed, several authors report that the G6PD deficiency is an anomaly linked to sex because the abnormal gene responsible for the deficiency is located on the $\mathrm{X}$ chromosome. The study carried out by Beutler et al in 1993 reports that, the associated disease this G6PD deficiency is more common in men than in women [18].

The two deficits in our study were observed in the age group 18 to 25 years. In the study by AMADOU et al in 2005 in Mali on G6PD deficiency in blood donors from the CNTS BAMAKO found that the G6PD deficiency affected the age group from 26 to 35 years [13].

In our study, the correlation between hemoglobin and the enzymatic activity of G6PD in non-deficient patients is statistically significant with a significance level $\mathrm{p}=0.0021$. Strangely, the difference between these two parameters did not show statistically significant differences in women unlike men. On the other hand, in the study by ADU et al in 2016 in Ghana on the deficiency of glucose-6-phosphate dehydrogenase and sickle trait among potential blood donors: a cross-sectional study in Berekum, Ghana, their data did not 
show any correlation between donor's hemoglobin levels and G6PD enzymatic activity [19].

Only seen in the men in our study, the correlation between hemoglobin and G6PD enzymatic activity of deficient people was statistically significant with a $\mathrm{p}$ value $=0.0076$. The deficits in our study had an average hemoglobin level of $10.45 \mathrm{~g} / \mathrm{dl}$, and this rate is lower than the norm set in our study from the start (Normal value in men; $\mathrm{N}: 13.5-17,5 \mathrm{~g} /$ dl). For the enzymatic activity of G6PD, the average of the deficient in our study, $2.83 \mathrm{IU} / \mathrm{g}$, is within the range of the standard set from the start (Value of the deficient, D: 2-3 IU / g). As the results of our study show, this deficit seems to have an impact on the hemoglobin level. In the event of a deficit in the enzymatic activity of G6PD, there would also be a drop in hemoglobin level. However, this observation deserves to be confirmed by a study on a much larger scale.

\section{Conclusion}

This study shows a prevalence of G6PD deficiency of $1.85 \%$. It was found to be predominantly male and mostly young. The blood donors in our study were distributed to two centers, the blood transfusion station (PTS) of the Talangai referral hospital and the blood transfusion station (PTS) of the Brazzaville CHU, and the deficits were observed at PTS of Talangaï referral hospital. The most dominant ethnicity in our study was that of the plateau followed by the pool and the cuvette. The deficit in our studies were from the plateau. It is therefore essential to invest in a much larger study in the population of blood donors vis-à-vis the G6PD deficiency to determine a prevalence closer to the reality of this deficiency in our country in order to draw the most valid conclusions in regions and make suggestions on transfusion policy.

\section{References}

[1] Nguetse $\mathrm{CN}$ et al. Glucose-6-phosphate dehydrogenase deficiency and reduced hemoglobin levels in African children with severe malaria. 2016, 15 (1): 346.

[2] Wajcman $\mathrm{H}$ et al. Déficits en glucose-6-phosphatedéshydrogénase. EMC - Hematology 2006; 13-006-D-10, 9 p.

[3] Yamoul M (2016). Anémie hémolytique par déficit en G6PD chez l'enfant. Université Mohamme V.

[4] Salvador A, Savageau MA. Quantitative evolutionary design of glucose 6-phosphate dehydrogenase expression in human erythrocytes. Proc Natl Acad Sci U S A 2003; 100: 14463—8.

[5] SARAH A et al (2001). Haplotype diversity and linkage Desiquilibrium at Human Glucose 6-phosphate dehydrogenasse: Recent origin of alleles that confer malaria resistance. Science, July 20, vol. 293, Issue 55229; 455-462.

[6] SRIDEVI SUKUMAR et al (2002). Glucose 6- phosphate dehydrogenase gene mutation in India productin drug-induced haemolytic anemia, Bristish Journal of Haemtology, 116, 671672 .

[7] Owen, R., Karl Landsteiner and the first human marker locus. Genetics, 2000. 155 (3): p. 995-8.

[8] LUCIO LUZZATTO et al (2006). Glucose 6-phosphate dehydrgenase deficiency: From genotype to phenotype. Haematological/ the haematology journal/, 91 (10)/ 1303-1306.

[9] AMADOU DIAWARA et al (2005). Déficit en G6PD chez les donneurs de sang du C. N. T. S. de Bamako. Th: Ph: Bamako,.-36p. 55.

[10] Aubry (2014), Deficits enzymatiques hereditaires du globule rouge.

[11] Estelle Noêla HV (2004). Prévalence du déficit en glucose-6phosphate déshydrogénase (G6PD) et de l'association drépanocytose et déficit en g6pd chez les nouveau-nés dans la ville de Ouagadougou (Burkina-Faso). Université de Ouagadougou.

[12] Mégarbane (2008)., Déficit en glucose-6-phosphate déshydrogénase: quand $\mathrm{y}$ penser et quelles précautions prendre ? Glucose-6-phosphate dehydrogenase deficiency. B. P,; 17 (4): 399-406.

[13] Guitteye H et al (2003). La Sélection du donneur de sang par un dosage pré-don de l'hémoglobine. Thèse pharmacie Bamako ${ }^{\circ} 48$.

[14] Traore Oumou et al (2002). Phénotype érythrocytaires dans les systèmes de groupes sanguins immunogènes chez les donneurs de sang de Bamako. Thèse pharmacie Bamako.

[15] Olivier MUKUKU et al (2016). Profil é épidémiologique et séroprévalence des donneurs de sang aux cliniques universitaire de Lubumbashi, République démocratique du Congo. Panafrican Medical Journal P: 4.

[16] ADU et al (2016). Deficit en G6PD. Déficit En Glucose-6Phosphate Déshydrogénase Et Faucille Trait parmi les donneurs de sang potentiels: une étude transversale à Berekum, Ghana. P: 7.

[17] Akanni et al (2010). Deficit G6PD. Déficit en glucose-6phosphate déshydrogénase chez des donneurs de sang et des nouveau-nés atteints de jaunisse à Osogbo, Nigeria. P: 1-4.

[18] Beutler E et al. Hematologically important mutation: Glucose6-phosphate deshydrogenase. Blood cells Mol Dis. 2002-MarApr, 28 (2): 93-103.

[19] HUSSEN et al (2011). Prevalence of glucose-6-phosphatedeshydrogenase (G6PD) deficiency (Favism) in Thamar province- Republique of yemen. P: 3 (1), 12-19. 